\title{
USING RASBERRY Pi 3 AND FACE DETECTION METHOD TO TAKE THE ATTENDANCE OF THE STUDENT IN THE CLASSROOM AND OTHER SECURITY PURPOSES
}

\author{
Debopama Ghosh, Arkaprabha Lodh, Debosama Ghosh
}

Dept.of.Computer Science, Institute of Engineering and Management, Kolkata, India

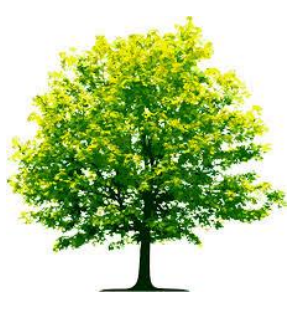

Keywords: Open $C V$, Raspberry Pi, Cascade, LBPH recognizer,

Viola-Jones framework

\begin{abstract}
A B S T RA C T
Attendance for the students is an important task in class. When done manually it generally wastes a lot of productive time of the class. This proposed solution for the current problem is to automation of attendance system using face recognition. Face is the main identification for any human to know.
\end{abstract}

Citation: Debopama Ghosh, Arkaprabha Lodh, Debosama Ghosh (2018). Using Rasberry Pi 3 And Face Detection Method To Take The Attendance Of The Student In The Classroom And Other Security Purposes. International Journal of Advanced Multidisciplinary Scientific Research (IJAMSR ) ISSN:2581-4281 Vol 1, Issue 6, August, 2018, \#Art.620, pp 100- 